\title{
The cytotoxic effect and glucose uptake modulation of Baeckea frutescens on breast cancer cells
}

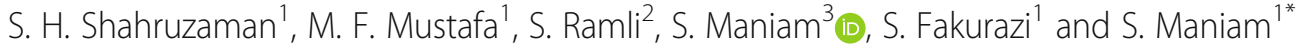

\begin{abstract}
Background: Baeckea frutescens (B. frutescens) of the family Myrtaceae is a plant that has been used in traditional medicine. It is known to have antibacterial, antipyretic and cytoprotective properties. The objective of this study is to explore the mechanism of $B$. frutescens leaves extracts in eliminating breast cancer cells.

Method: $B$. frutescens leaves extracts were prepared using Soxhlet apparatus with solvents of different polarity. The selective cytotoxicity of these extracts at various concentrations (20 to $160 \mathrm{\mu g} / \mathrm{ml}$ ) were tested using cell viability assay after 24, 48 and $72 \mathrm{~h}$ of treatment. The IC 50 value in human breast cancer (MCF-7 and MDA-MB-231) and mammary breast (MCF10A) cell lines were determined. Apoptotic study using AO/PI double staining was performed using fluorescent microscope. The glucose uptake was measured using 2-NBDG, a fluorescent glucose analogue. The phytochemical screening was performed for alkaloids, flavonoids, tannins, triterpenoids, and phenols.

Results: $B$. frutescens leaves extracts showed $I C_{50}$ value ranging from $10-127 \mu \mathrm{g} / \mathrm{ml}$ in MCF-7 cells after $72 \mathrm{~h}$ of treatment. Hexane extract had the lowest $I C_{50}$ value $(10 \mu \mathrm{g} / \mathrm{ml})$, indicating its potent selective cytotoxic activity. Morphology of MCF-7 cells after treatment with B. frutescens extracts exhibited evidence of apoptosis that included membrane blebbing and chromatin condensation. In the glucose uptake assay, B. frutescens extracts suppressed glucose uptake in cancer cells as early as $24 \mathrm{~h}$ upon treatment. The inhibition was significantly lower compared to the positive control WZB117 at their respective $I_{50}$ value after $72 \mathrm{~h}$ incubation. It was also shown that the glucose inhibition is selective towards cancer cells compared to normal cells. The phytochemical analysis of the extract using hexane as the solvent in particular gave similar quantities of tannin, triterpenoids, flavonoid and phenols. Presumably, these metabolites have a synergistic effect in the in vitro testing, producing the potent $I C_{50}$ value and subsequently cell death.
\end{abstract}

Conclusion: This study reports the potent selective cytotoxic effect of $B$. frutescens leaves hexane extract against MCF-7 cancer cells. B. frutescens extracts selectively suppressed cancer cells glucose uptake and subsequently induced cancer cell death. These findings suggest a new role of $B$. frutescens in cancer cell metabolism.

Keywords: Baeckea frutescens, Glucose uptake, Apoptosis, Oxidative phosphorylation, Breast cancer

\footnotetext{
* Correspondence: sandra@upm.edu.my

${ }^{1}$ Department of Human Anatomy, Faculty of Medicine and Health Sciences,

Universiti Putra Malaysia (UPM), 43400 Serdang, Selangor Darul Ehsan,

Malaysia

Full list of author information is available at the end of the article
}

(c) The Author(s). 2019 Open Access This article is distributed under the terms of the Creative Commons Attribution 4.0 International License (http://creativecommons.org/licenses/by/4.0/), which permits unrestricted use, distribution, and reproduction in any medium, provided you give appropriate credit to the original author(s) and the source, provide a link to the Creative Commons license, and indicate if changes were made. The Creative Commons Public Domain Dedication waiver (http://creativecommons.org/publicdomain/zero/1.0/) applies to the data made available in this article, unless otherwise stated. 


\section{Background}

Survival of patients with metastatic breast cancer has not improved significantly despite the development in early diagnosis and treatments of breast cancer [1]. Multidrug resistance remains the principal obstacle in treating metastatic breast cancer [1].

The inability of cells to respond to stress and repair damage underlies many forms of cancer. A fundamental characteristic of cancer cells is their ability to sustain indefinite cycles of proliferation. One of the mechanism which contributes to the inhibition of tumour growth is by impairing cancer cell metabolism. Reprogramming of core metabolism in tumours confers a selective growth advantage such as the ability to evade apoptosis and/or enhance cell proliferation, promotes tumour growth and progression [2]. The high proliferation rate in cancer cells requires increased energy, and most cancer cells rely on glycolysis as their primary energy source. Pharmacological inhibition of glucose uptake or glycolytic enzymes activity serves as a potential target for cancer therapeutic [3]. To date, natural product plays a dominant role in the discovery of leads for the development of drugs [4].

Baeckea frutescens (family Myrtaceae and subfamily Myrtoideae) is a small aromatic low-growing tree found in Peninsular Malaysia, Sumatra, Southern China and Australia [5, 6]. Traditional medicinal properties of $B$. frutescens were reported in Thailand, Malaysia, Sumatra, Borneo, Sulawesi, and New Guinea in treating influenza, dyspepsia, jaundice, dysentery, measles and irregular menstrual cycles [7]. The aromatic property of $B$. frutescens is used to ease mental distress as well as a tonic [8]. Several compounds were isolated from the leaves of B.frutescens which include sesquiterpenes [9], phloroglucinols [10-13], chromones [14, 15], flavonoids [16, 17], cyclopentenones and furanones [18], and essential oil [19]. Of note, flavonoid was reported in B.frutescens root extracts [20-23]. Cyclopentenones and phloroglucinols were shown to have cytotoxic effect against human pancreatic, lung and breast cancer cell lines [10, 12, 18].

Enhance glycolytic flux in cancer cells contributes to tumour development. One of the mechanism which contributes to the inhibition of tumour growth is by impairing cancer cell metabolism. Thus, it is interesting to explore the potential role of $B$. frutescens in regulating cellular metabolism as an approach in inducing cell death and preventing tumour growth and progression.

\section{Method}

\section{Extracts preparation}

B. frutescens or Cucur Atap was collected from Forest Research Institute Malaysia (FRIM) Research Station in Setiu, Terengganu and its voucher specimen was deposited at Institute of Bioscience, Universiti Putra Malaysia (voucher number: KLU 47909). The leaves of $B$. frutescens were air-dried under shade for 7 days and were pulverized into coarse powder [24]. The powder was grounded and filtered using $0.9 \mathrm{~mm}$ filter membrane by vacuum pump. The coarse powder was extracted using hexane, ethanol and water. B.frutescens leaves ethanol extracts were prepared according to Ahmad et al. [6] at 90\% (L90), 70\% (L70) and 50\% (L50). $111 \mathrm{~g}, 142 \mathrm{~g}$ and $200 \mathrm{~g}$ of coarse powder were weighed and extracted in 5 1 of ethanol to obtain L90, L70 and L50 respectively. All extraction was prepared by Soxhlet. A stock solution of each crude extract was prepared by suspending $100 \mathrm{mg}$ of extract in $1 \mathrm{~mL}$ of pure dimethylsulphoxide (DMSO) and mixed by sonication for $30 \mathrm{~min}$. The volume was adjusted to $1000 \mathrm{~mL}$ with culture media to provide assay solutions as required.

\section{Cell lines}

Human MCF-7 and MDA-MB-231 breast carcinoma cells (ATCC, USA) were grown in DMEM supplemented with $100 \mu \mathrm{g} / \mathrm{ml}$ streptomycin, $100 \mu \mathrm{g} / \mathrm{ml}$ penicillin and $10 \%$ FBS. Human mammary breast cell line, MCF10A cells (ATCC, USA) were cultured in DMEM/Ham's F-12 supplemented with $20 \mathrm{ng} / \mathrm{ml}$ epidermal growth factor (EGF), $0.01 \mathrm{mg} / \mathrm{ml}$ insulin, $500 \mathrm{ng} / \mathrm{ml}$ hydrocortisone and $5 \%$ horse serum. All cells were maintained at $37{ }^{\circ} \mathrm{C}$ in $5 \% \mathrm{CO}_{2}$.

\section{Cell viability assay}

The cytotoxicity effect of $B$. frutescens leaves extracts was determined by measuring the $\mathrm{IC}_{50}$ using cell viability assay as previously described by Mosmann [25]. Briefly, cells at a density of $5 \times 10^{3}$ cells/well were plated in 96-well microplates in triplicates and were treated for 24,48 and $72 \mathrm{~h}$ with extracts concentration ranging from 0 to $1000 \mu \mathrm{g} / \mathrm{ml}$. Etoposide served as a positive control whilst DMSO was the vehicle control (control). MTT (3-(4,5-dimethylthiazol-2-yl)-2,5-diphenyltetrazolium bromide) solution was added into each well and incubated for $4 \mathrm{~h}$ in dark. The formazan grains were dissolved in DMSO and the colour intensity was measured at $570 \mathrm{~nm}$ (wavelength range: $550-600 \mathrm{~nm}$ ) using an ELISA plate reader with the reference wavelength of higher than $650 \mathrm{~nm}$.

\section{Glucose consumption assay}

2-NBDG (2-[N-(7-nitrobenz-2-oxa-1,3-diazol-4-yl) amino]-2-deoxy-d-glucose) was used to measure glucose uptake as previously described by Hassanein et al. [26]. Cells were seeded (0-30,000 cells/well) in black flat-bottomed 96-well microplates in triplicates. After overnight incubation, cells were treated with B.frutescens leaves extracts for 24, 48 and $72 \mathrm{~h}$. WZB117 $(10 \mu \mathrm{M})$ served as a positive glucose transport inhibitor and DMSO was used 
as the vehicle control (control). The cells were incubated with 2-NBDG $(100 \mu \mathrm{M})$ for $10 \mathrm{~min}$ at $37^{\circ} \mathrm{C}$ and the reaction was halted by adding two-fold volume of ice-cold PBS. The fluorescent signal was measured using the 485 $\mathrm{nm}_{\mathrm{ex}}$ and $520 \mathrm{~nm}_{\text {emiss }}$ filter set.

\section{Acridine Orange and Propidium iodide staining}

Cell death was detected using propidium iodide (PI) (Sigma-Aldrich, USA) and acridine-orange (AO) (SigmaAldrich, USA) double staining and examined under fluorescence microscope as previously described by [27]. Briefly, $1 \times 10^{6}$ MCF-7 cells $/ \mathrm{ml}$ were plated in 6-well plate. The $\mathrm{IC}_{50}$ concentration were used for all five extracts and DMSO served as the vehicle control (control). Cells were treated for 24,48 and $72 \mathrm{~h}$. The treated cells were trypsinized and centrifuged at $1000 \times g$ for $10 \mathrm{~min}$. After rinsing with PBS, the supernatant was discarded and $10 \mu \mathrm{l}$ fluorescent dyes, $\mathrm{AO}(10 \mu \mathrm{g} / \mathrm{ml})$ and PI $(10 \mu \mathrm{g} / \mathrm{ml})$, were added into the cellular pellet at equal volumes. Stained cells were transferred onto a glass slide and observed under ultraviolet (UV)-fluorescence microscope (Olympus, Japan) within $30 \mathrm{~min}$.

\section{Phytochemical screening}

$10 \mu \mathrm{L}$ of B.frutescens leaves extracts $(1 \mathrm{mg} / \mathrm{mL}$ ethanol) were tested for the presence of tannins, alkaloids, triterpenoids, flavonoids, phenols and alkaloids. The colour intensity was graded as either very high $(++++)$, high $(+++)$, moderate $(++)$, low $(+)$, or not detected $(-)$ compared to the positive control. The quantitative results were determined as previously described by Hisam et al. with slight modification [28]. The absorbance (Wavelength range: $435-635 \mathrm{~nm}$ ) was measured by using an ELISA plate reader (Tecan 200, Switzerland).

\section{Total tannins content}

The intensity of blue colour formation after adding five drops of 5\% ferric chloride (Sigma Aldrich) to the extract were measured at $560 \mathrm{~nm} .0 .01 \mathrm{~g} / \mathrm{ml}$ tannic acid (Sigma Aldrich) was used as the positive control.

\section{Total triterpenoids content}

The leaves extracts in chloroform were added with concentrated sulfuric acid and the colour intensity was measured at $635 \mathrm{~nm} .0 .01 \mathrm{~g} / \mathrm{ml}$ cholesterol (Sigma Aldrich) was used as the positive control.

\section{Total flavonoids content}

$10 \%$ of lead acetate were added to the leaves extracts until yellow precipitate was formed and the colour intensity was measured at $590 \mathrm{~nm} .0 .01 \mathrm{mg} / \mathrm{ml}$ quercetin (Sigma Aldrich) was used as the positive control.

\section{Total phenols content}

Presence of phenols was measured by adding 10\% ferric chloride (Sigma Aldrich) solution to the leaves extracts. The colour intensity was measured at $490 \mathrm{~nm} .0 .01 \mathrm{~g} / \mathrm{ml}$ quercetin was used as the positive control.

\section{Total alkaloids content}

Brown precipitate that was formed when Dragendorff's reagent (Sigma Aldrich) were added to the extract indicates the presence of alkaloid. The colour intensity was measured at $435 \mathrm{~nm} . .01 \mathrm{~g} / \mathrm{ml}$ quinine sulfate (Sigma Aldrich) was used as the positive control.

\section{Statistical analysis}

All experiments were conducted at least three times unless otherwise indicated and the data were expressed as mean \pm SEM (Standard Error of the Mean). Statistical analyses were performed using SPSS (version 20) statistical software. The treatment effects were analysed using one way analysis of variance (ANOVA), followed by Bonferroni post-hoc test. $p$-value less than $0.01(p<0.01)$ was considered to be statistically significant.

\section{Results}

Selective cytotoxic effect of $B$. frutescens on breast cancer cells

The cytotoxic effect of $B$. frutescens against MCF-7 were determined at 24, 48 and $72 \mathrm{~h}$ of incubation. After $24 \mathrm{~h}$ of incubation, no cytotoxic effect against MCF-7 cells was observed (Fig. 1a). Interestingly, two extracts (HX and $\mathrm{L} 50$ ) showed $\mathrm{IC}_{50}$ values of $22 \pm 0.04 \mu \mathrm{g} / \mathrm{ml}$ and $160 \pm 0.04 \mu \mathrm{g} / \mathrm{ml}$, respectively after $48 \mathrm{~h}$ of incubation (Figs. 1a and 2). When the incubation time was increased to $72 \mathrm{~h}$, all extracts showed $\mathrm{IC}_{50}$ values ranging from 10 to $124 \mu \mathrm{g} / \mathrm{ml}$ (Figs. 1a and 2). Of note, the extracts were also tested against MDA-MB-231 cancer cells at three incubation time; 24,48 and $72 \mathrm{~h}$. The $\mathrm{IC}_{50}$ value of all extracts against MDA-MB-231 cells after 24 and $48 \mathrm{~h}$ of incubation cannot be calculated (Fig. 1a). Only hexane extract displayed $\mathrm{IC}_{50}$ value of $80 \pm 0.32 \mu \mathrm{g} / \mathrm{ml}$ after $72 \mathrm{~h}$ of incubation (Fig. 1a). This shows that B. frutescens extracts has low cytotoxic effect against MDA-MB-231 compared to MCF-7 cells.

The in vitro cytotoxicity of $B$. frutescens extracts were evaluated in normal mammary epithelial cells, MCF10A. MCF10A cells were incubated in three different concentrations of $B$. frutescens extracts; a concentration lesser than the $\mathrm{IC}_{50}$ value obtained from MCF-7 cells, the $\mathrm{IC}_{50}$ value and a concentration greater than the $\mathrm{IC}_{50}$ value obtained from MCF-7 cells. All extracts except L50 showed $80 \%$ of cell viability at their respective $\mathrm{IC}_{50}$ values after $72 \mathrm{~h}$ of incubation with $B$. frutescens extracts (Fig. 1b). 
a

\begin{tabular}{lcccccc}
\hline & \multicolumn{2}{c}{ 24 hours } & \multicolumn{2}{c}{ 48 hours } & \multicolumn{2}{c}{$\mathbf{7 2}$ hours } \\
\cline { 2 - 7 } & MCF-7 & MDA-231 & MCF-7 & MDA-231 & MCF-7 & MDA-231 \\
\hline HX & ND & ND & $22 \pm 0.04$ & ND & $10 \pm 0.33$ & $80 \pm 0.32$ \\
L90 & ND & ND & ND & ND & $84 \pm 0.69$ & ND \\
L70 & ND & ND & ND & ND & $108 \pm 0.70$ & ND \\
L50 & ND & ND & $160 \pm 0.04$ & ND & $124 \pm 0.29$ & ND \\
WL & ND & ND & ND & ND & $115 \pm 0.13$ & ND \\
\hline
\end{tabular}

b

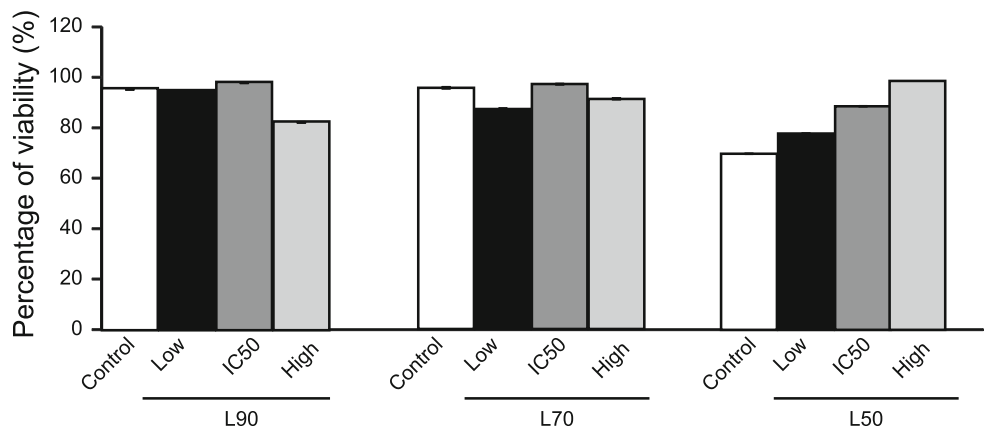

Extracts $(\mu \mathrm{g} / \mathrm{ml})$

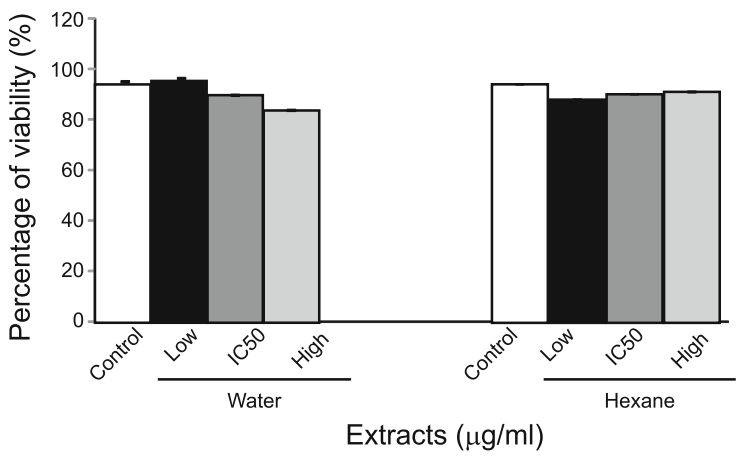

Legend

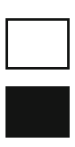

Control

IC50 value

Lower than IC50 value

Higher than IC50 value

Fig. 1 Effects of $B$. frutescens leaves extracts on cell viability. a $I C_{50}$ values were determined using cell viability assay in MCF-7 and MDA-MB 231 cells treated with either hexane, L90, L70, L50 or water extracts after 24, 48 and 72 h. b Normal mammary epithelial cells (MCF-10A) were treated with either (a) $L 90, L 70$ or $L 50$ or (b) water or hexane extract of $B$. frutescens leaves for $72 \mathrm{~h}$ at three different concentrations; lower than $I C_{50}$ value (low), $I_{50}$ value $\left(I C_{50}\right)$ and higher than $I C_{50}$ value (high). Data is expressed as mean \pm standard error mean based on three independent experiments with triplicate wells for each concentration

\section{Apoptosis induction in breast cancer cells after $B$.}

\section{frutescens treatment}

Morphological changes in MCF-7 cells were observed at 24,48 and $72 \mathrm{~h}$ of incubation with five B.frutescens extracts at their respective $\mathrm{IC}_{50}$ values. At $24 \mathrm{~h}$, the cells were stained green with intact nucleus (Fig. 3b).
Interestingly, after $48 \mathrm{~h}$ of incubation with $\mathrm{HX}$ and L50, chromatin condensation and membrane blebbing were noted (Fig. 3b). As shown in Fig. 3b, cells displayed orange coloured nuclei indicating cell death induction after $72 \mathrm{~h}$ incubation with B.frutescens extracts. 


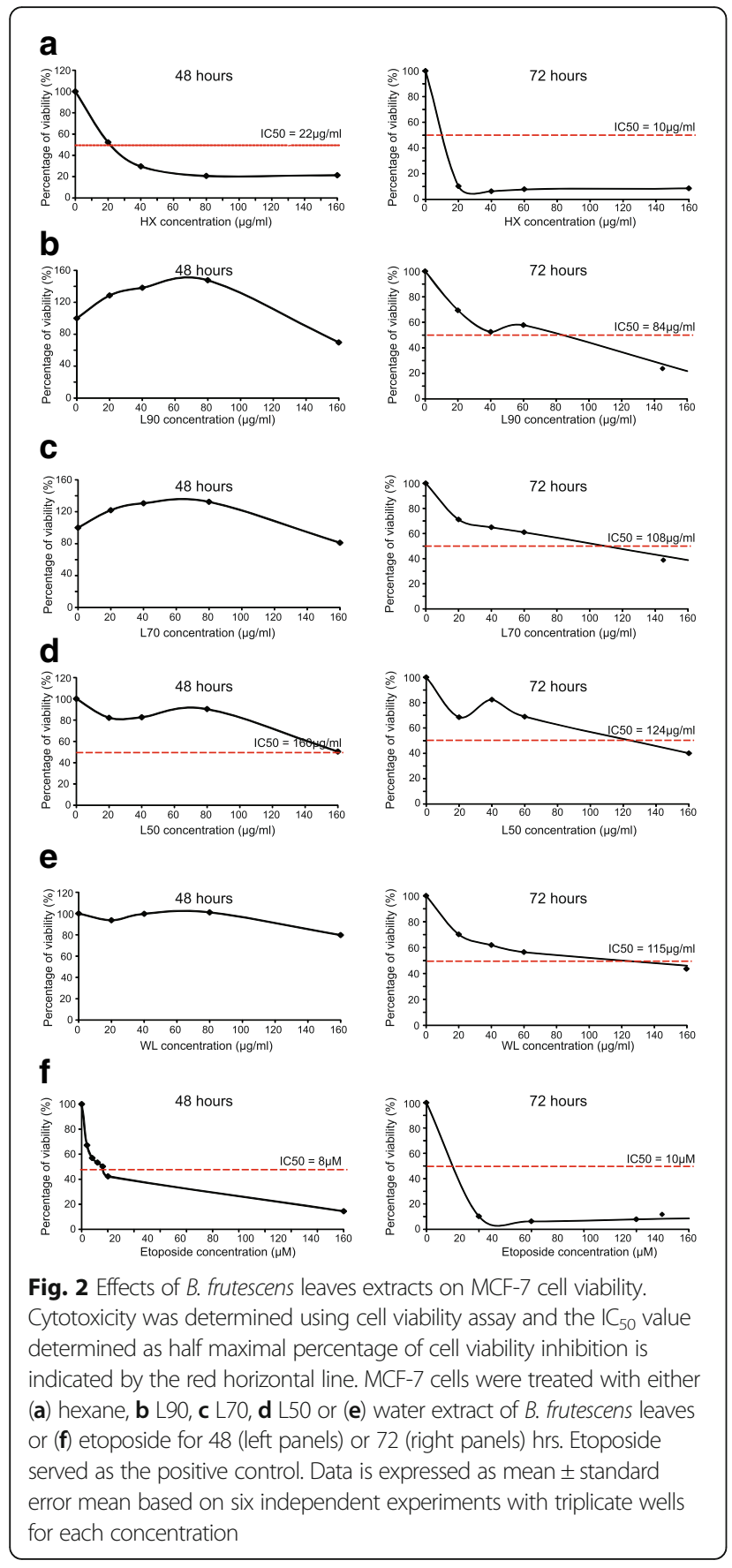

Glucose uptake inhibition after $B$. frutescens treatment To investigate the effect of $B$. frutescens extracts on glucose uptake in MCF-7 cells, the cells were incubated in the presence of five extracts at three different concentrations for 24,48 and $72 \mathrm{~h}$. All extracts except L70 and water extracts, significantly inhibited glucose uptake compared to control at all time points and concentration (Fig. 4).

At $24 \mathrm{~h}$, all extracts except for L70 and water, significantly inhibited glucose uptake compared to the positive a

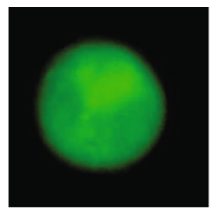

Viable

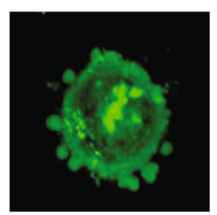

Membrane

blebbing

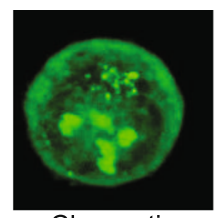

Chromatin condensation

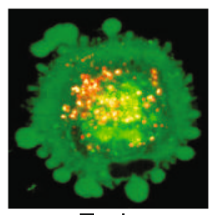

Early apoptotis b
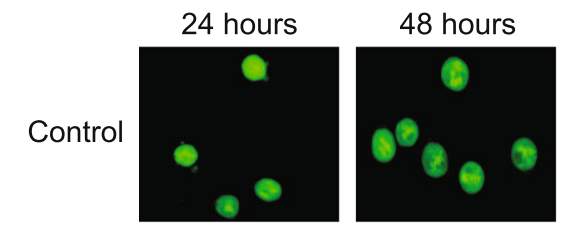

72 hours

HX
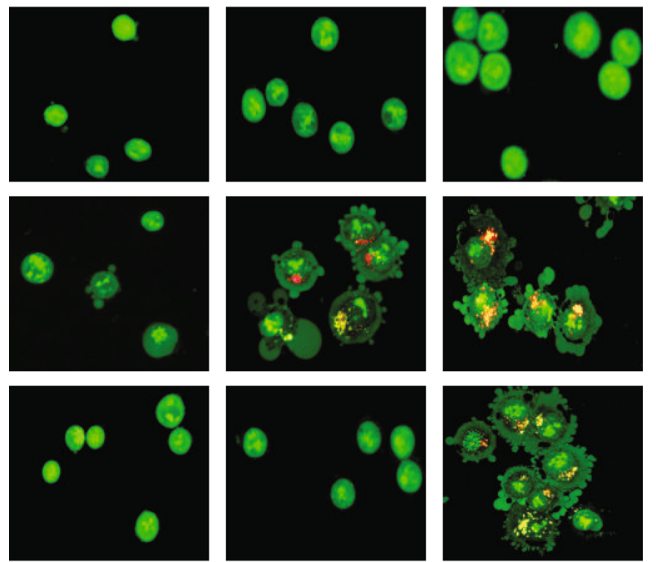

L90
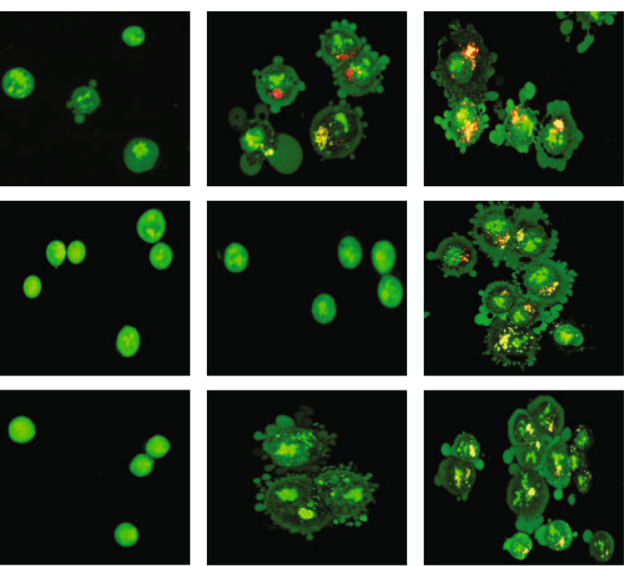

$\mathrm{L} 70$
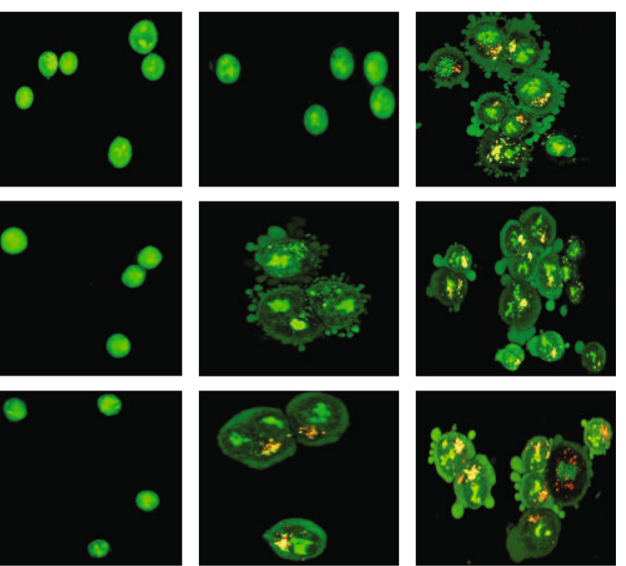

L50
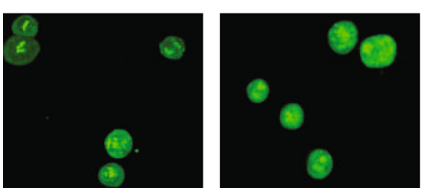

WL
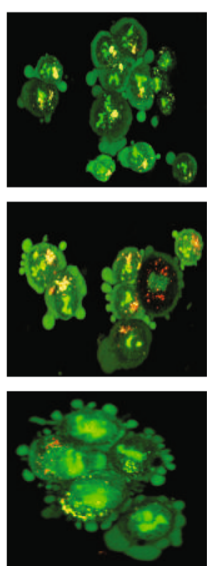
(See figure on previous page.)

Fig. 3 Morphological observation of $B$. frutescens leaves extracts treated MCF-7 cells using AO/PI dual staining at X400

magnifications. a Observation of morphological changes in MCF-7 cells. Viable cells are green stained cells with intact nucleus, condensed chromatin marked by intense green stained chromatin, membrane blebbing indicated by the outgrowth of plasma membrane and apoptotic cells are characterised by nuclear disintegration and leakage of plasma membrane. b MCF-7 cells were either treated with DMSO vehicle control (control) or B. frutescens extracts (hexane, L90, L70, L50 and water) for 24,48 and $72 \mathrm{~h}$ at their respective $\mathrm{IC}_{50}$ values

control, WZB117 and control at their $\mathrm{IC}_{50}$ value. However, only L50 showed significant decrease in glucose uptake compared to WZB117 and control after $48 \mathrm{~h}$ of incubation for all three concentrations (Fig. 4d). Interestingly, all extracts at $\mathrm{IC}_{50}$ value showed significant decrease in glucose uptake after $72 \mathrm{~h}$ of incubation compared to cells treated with WZB117 and control (Fig. 4). Of note, no glucose uptake inhibition was observed in MCF10A treated cells.

\section{Secondary metabolites identified in leaves and branches of $B$. frutescens}

Hexane, ethanol and water extracts showed the presence of various quantities of flavonoids, alkaloids, phenols, triterpenoids and tannins as indicated in Table 1. Alkaloid was undetected in all leaves extracts except very low amount in L90 and L70. Tannin was detected in all five leaves extracts with value of more than 100 (Additional file 1: Table S1). Interestingly, in the qualitative estimation of the secondary metabolites in B. frutescens showed that hexane extract has equal ratio of tannin, triterpenoids, flavonoid and phenols (Table 1).

\section{Discussion}

Tumours are collection of diverse cells with distinct molecular and morphological signatures [29]. Of note, established biomarkers in breast cancer such as oestrogen receptor, progesterone receptor and HER2 are used in clinical decision-making [30]. In this study, $B$. frutescens extracts were tested in two distinct human breast cancer cell lines: a human breast cancer cell line positive for oestrogen and progesterone receptors and negative for HER-2 receptor and a triple negative cell line, MCF-7 and MDA-MB-231, respectively. MCF-7 cells were found to be more sensitive to $B$. frutescens extracts effect in inducing cell death compared to MDAMB-231 cells (Fig. 2a). Hence, the subsequent experiments to determine the role of $B$. frutescens in eliminating breast cancer cells were focused on MCF-7 cells.

Cell viability assay and AO/PI staining were used to investigate the cytotoxicity properties of $B$. frutescens leaves extracts on MCF-7 cells. This assay is a non- radioactive measurement of cell viability. Our results indicate hexane extract showed potent selective cytotoxicity against MCF-7 cells at $48 \mathrm{~h}$ and $72 \mathrm{~h}$ with $\mathrm{IC}_{50}$ value less than $20 \mu \mathrm{g} / \mathrm{ml}$ (Figs. 1a and 2). According to the protocol from the American National Cancer Institute (NCI) recommends a crude extract is considered to possess significant cytotoxic activity with $\mathrm{IC}_{50}$ value $\leq 20 \mu \mathrm{g} / \mathrm{ml}$, whilst this value was deemed at $\leq 4 \mu \mathrm{g}$ / $\mathrm{ml}$ for a pure compound [31].

The apoptotic effect of these extracts were further established using AO/PI staining where cells predominantly displayed changes that are known to be associated to apoptotic features namely membrane blebbing and chromatin condensation (Fig. 3). Apoptosis is accompanied by series of dramatic cellular morphological changes which includes cell contraction, dynamic membrane blebbing and nuclear disintegration that ultimately lead cells to fragment into apoptotic bodies.

The altered pattern in glucose metabolism in cancer cells was initially described by Otto Warburg as aerobic glycolysis. Hypoxic cancer cells rely heavily on glucose transporters for their survival through the uptake of glucose and subsequent glycolysis. Many cancer cells overexpress GLUT1 [32]. Previous studies on compounds and extracts from $B$. frutescens were tested on cancer cells that exhibit upregulated glucose transporters, mainly GLUT1. Thus, in this study, effect of $B$. frutescens extracts on GLUT1 was investigated.

Glucose is an essential metabolic substrate in cells. GLUT1 is widely distributed in normal tissue and overexpressed in many tumours, including hepatic, pancreatic, breast, oesophageal, brain, renal, lung, cutaneous, colorectal, endometrial, ovarian, and cervical cancers [33]. One major concern about glucose transport inhibitors is the ability to selectively inhibit GLUT1 in tumour but not in normal cells. To address this concern, glucose inhibition assay was performed in the breast cancer cell line MCF-7 and normal mammary cell line MCF10A. This study demonstrated that $B$. frutescens extracts inhibited glucose uptake significantly in cancer cell lines and not in their non-cancerous counterparts (Fig. 4).

To date, knowledge on the mechanism of B. frutescens in eliminating cancer cells is limited. This study described a novel role of $B$. frutescens extracts in metabolic reprogramming through their ability in suppressing glucose uptake in cancer cells (Fig. 4). However, the inhibitory effect on GLUT1-mediated glucose uptake may not be the main mechanism in $B$. frutescens in inducing cell death as the inhibition does not correlate with the potency of the extracts which was observed in the MTT assay (Figs. 1, 2 and Table 1). There are several pathways that affect glucose regulation in cancer cells. Disrupting PI3K signalling and selective blocking of GLUT1 transporter lead to decreased glucose uptake by tumours 


\section{a}
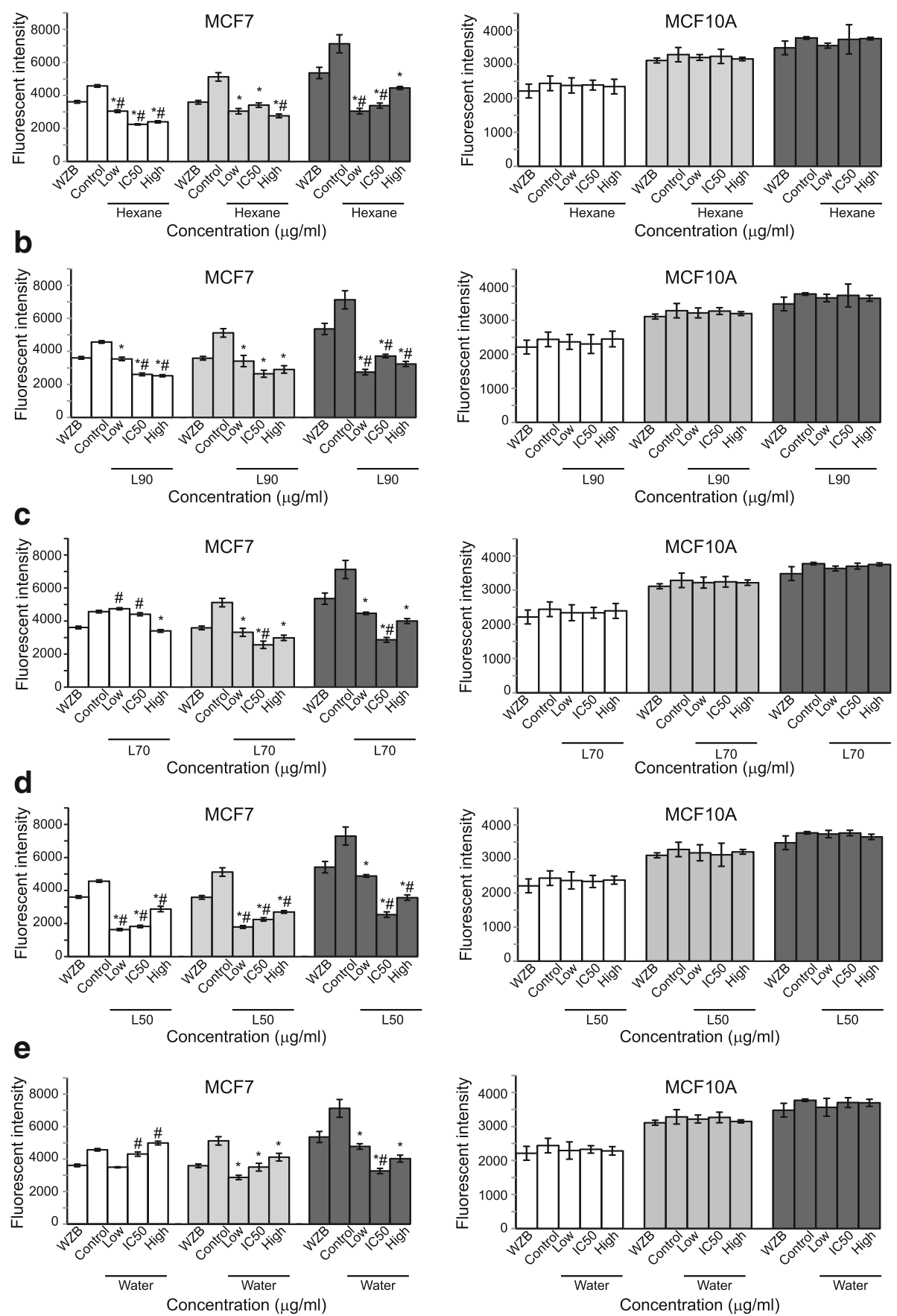

24 hours

48 hours

72 hours

Fig. 4 Inhibition of glucose uptake of $B$. frutescens leaves extracts after 24, 48 and 72 h of incubation MCF-7 (left panels) or MCF10A (right panels) cells were either treated with DMSO vehicle control (control) or B. frutescens leaves extracts (a) hexane, b L90, c L70, d L50 or (e) water for 24, 48 and $72 \mathrm{~h}$ at three different concentrations; lower than $I C_{50}$ value (low), IC 50 value $\left(I C_{50}\right)$ and higher than $I C_{50}$ value (high). WZB1 17 served as the positive control. Data is expressed as mean \pm standard error mean based on four independent experiments with triplicate wells for each concentration. ${ }^{*} p<0.01$, compared with control, \# $p<0.01$ compared with the positive control (WZB117) 
Table 1 Qualitative analysis of B. frutescens leaves phytochemical constituents

\begin{tabular}{lccccc}
\hline Compound & HX & L90 & L70 & L50 & WL \\
\hline Tannin & ++ & +++ & +++ & ++ & +++ \\
Triterpenoids & ++ & ++ & ++ & ++ & + \\
Flavonoid & ++ & ++ & ++ & +++ & +++ \\
Alkaloids & - & + & + & - & - \\
Phenols & ++ & ++ & ++ & ++ & ++ \\
\hline
\end{tabular}

$+++=$ highly present, $++=$ moderately present,$+=$ lowly present,$-=$ not determined

$[3,34]$. Ritonavir, fasentine, genistein, STF13 and WZB117 are anticancer drugs designed to target glucose transporter GLUT1 and exert antitumour effect by inhibiting glucose uptake, thus leading to cell death through glucose deprivation $[3,35]$. Natural compounds such as cryptocaryone [36, 37], methylxanthines [38] and resveratrol [39] have been recently identified to inhibit glucose uptake either via direct binding to GLUT1 or indirectly by influencing glucose metabolism.

Previous studies have reported on several metabolites extracted from $B$. frutescens and structure of these metabolites were elucidated [5-7, 9-16, 18-24, 40-49]. Prior studies on flavanoids (BF4, BF5 and BF6) [46], phloroglucinols (BF1 and BF2) [10] and tasmanonebased meroterpenoid (Frutescone A -G) [11] extracted from the polar fraction of $B$. frutescens leaves showed moderate cytotoxic activity after $24 \mathrm{~h}$ of treatment against leukaemic, hepatocellular carcinoma and colorectal adenocarcinoma cells with $\mathrm{IC}_{50}$ ranging from 0.25-50 $\mathrm{M}$. The studies on phloroglucinols obtained from the non-polar fraction of $B$. frutescens leaves showed cytotoxicity activity against pancreatic, breast and lung cancer cells after $72 \mathrm{~h}$ of treatment $[12,44]$.

The curative properties of medicinal plants are attributed to the presence of various secondary metabolites such as alkaloids, flavonoids, glycosides, natural phenols and terpenoids. In the continuous effort to discover phytochemical compounds from B.frutescens, five secondary metabolites, namely tannins, triterpenoids, flavonoids, alkaloids and phenol were tested in the preliminary screening. Hexane is able to extract the most non-polar compounds of all the secondary metabolite. Based on the phytochemical analysis, the active secondary metabolites are of very non-polar in nature, with almost equal amounts of the tannin, flavonoid and phenols. However, the absences of alkaloids is indicative of this nitrogen containing compound is not the active metabolite (Table 1 and Additional file 1: Table S1). Generally, tannin, flavanoid and phenol have been reported for their anticancer properties [50-52]. Potent anticancer activities have been observed in tannins with multiple mechanisms, such as apoptosis, cell cycle arrest, and inhibition of invasion and metastases [51]. This potentially indicates the overall activity of hexane extract is a result of the synergistic combination of the secondary metabolites especially tannin, flavonoid and phenol As the polarity of the solvent is increased from hexane to absolute ethanol, the total amount of triterpenoids, flavonoids and alkaloids increased, as these compounds usually have polar heteroatoms such as nitrogen, oxygen and sulphur. The most polar compounds in the leaves eventually were extracted when water was used as the extracting solvent.

In summary, from the five $B$. frutescens leaves extracts tested, hexane extract showed the most selectively potent cytotoxic activity against breast cancer cell lines, mainly MCF-7 cells. This finding corroborated with the morphological changes observed upon the extract treatment. The hexane extract also selectively inhibited glucose uptake in MCF-7 cells as early as $24 \mathrm{~h}$ after treatment.

Cancer is a systemic disease which involves multiple biological network, pathways, genes and proteins. Identification of single compound has shown great success; nonetheless, the effect of single compound is not always ideal [53]. The multiple constituents in B. frutescens leaves extracts suggest these extracts may have multiple targets and the efficacy can be achieved by the synergistic and dynamic interaction of multiple constituents. The present study reports the potent cytotoxic effect of B. frutescens leaves extracts against breast cancer cells and its novel role in cancer cell metabolism. However, additional studies on synergism and isolation of B.frutescens targeting the fractions showing the highest biological activity would be of great interest.

\section{Conclusions}

This study highlights the selective anti-cancer properties of $B$. frutescens in breast cancer cells. MCF-7 cells were 
more susceptible to $B$. frutescens-mediated cytotoxic effect compared to MDA-MB2-31 cancer cells. The hexane extract showed the most potent effect in inducing cell death with $\mathrm{IC}_{50}$ value of less than $20 \mu \mathrm{g} / \mathrm{ml}$ at 48 and $72 \mathrm{~h}$ of incubation. Limited publication is available regarding the property of hexane extract isolated from $B$. frutescens. Hence, correlating the potent cytotoxic effect of the hexane extract and its chemical constituents will be pertinent in determining therapeutically active constituent present in B. frutescens. Moreover, this study reports the novel role of $B$. frutescens in glucose-uptake inhibition in breast cancer cells. The mechanism of $B$. frutescens extracts in modulating glucose metabolism warrants for further investigation.

\section{Additional file}

Additional file 1: Table S1. Phytochemical constituent of $B$. frutescens leaves in $1 \mu \mathrm{g}$. A table listing the quantitative of the major secondary metabolites in $B$. frutescens leaves. (DOCX $18 \mathrm{~kb}$ )

\section{Abbreviations}

2-NBDG: 2-[N-(7-nitrobenz-2-oxa-1,3-diazol-4-yl) amino]-2-deoxy-d-glucose; AO: Acridine-orange; DMEM: Dulbecco's Modified Eagle Medium; DMSO: Dimethyl sulfoxide; HX: Hexane extract; $I C_{50}$ : half maximal inhibitory concentration; L50: B.frutescens leaves prepared at the ratio of 1:50 in ethanol; L70: B.frutescens leaves prepared at the ratio of 1:70 in ethanol; L90: B.frutescens leaves prepared at the ratio of 1:90 in ethanol; MTT: 3-(4,5dimethylthiazol-2-yl)-2,5-diphenyltetrazolium bromide; PI: Propidium iodide; WL: Water extract

\section{Acknowledgements}

Both MFM and SHS were supported by Graduate Research Fellowship from Universiti Putra Malaysia. SHS was also supported by MyBrain program from Malaysian Ministry of Higher Education.

\section{Authors' contributions}

SHS, SR, SF and $\mathrm{SM}^{1}$ participated in the design of the research; SF and SM ${ }^{1}$ guided the group of researchers. SHS contributed to plant collection, identification and extraction; SHS and MFM carried out the experiments and analysed the data under supervision of $\mathrm{SM}^{1}$. SHS and $\mathrm{SM}^{1}$ wrote the paper; $\mathrm{SM}^{3}$ and SF critically revised the manuscript. All authors read and approved the final manuscript.

\section{Funding}

This study was funded by Universiti Putra Malaysia (Programme Grant: Putra Grant GP-IPM/2014/9445100) to SM ${ }^{1}$. The funding body provided financial support and had no role in the design of the study, collection, analysis, interpretation of data, or writing the manuscript.

\section{Availability of data and materials}

The datasets analysed during the current study are available from the corresponding author on reasonable request.

\section{Ethics approval and consent to participate}

Not applicable.

\section{Consent for publication}

Not applicable.

\section{Competing interests}

The authors declare that they have no competing interests.

\section{Author details}

Department of Human Anatomy, Faculty of Medicine and Health Sciences, Universiti Putra Malaysia (UPM), 43400 Serdang, Selangor Darul Ehsan, Malaysia. ${ }^{2}$ Level 11, Building FF1, Faculty of Pharmacy, UiTM Cawangan Selangor, 42300 Puncak Alam, Selangor Darul Ehsan, Malaysia. ${ }^{3}$ School of Science, RMIT University, Melbourne, Victoria 3001, Australia.

Received: 22 May 2019 Accepted: 6 August 2019

Published online: 19 August 2019

\section{References}

1. Foukakis T, Fornander T, Lekberg T. Age-specific trends of survival in metastatic breast cancer: 26 years longitudinal data from a population -based cancer registry in Stockholm, Sweden. Breast Cancer Res Treat. 2011; 130:553-60. https://doi.org/10.1007/s10549-011-1594-z.

2. Hanahan D, Weinberg RA. Hallmarks of cancer: the next generation. Cell. 2011;144:646-74.

3. Vander Heiden MG, Cantley LC, Thompson CB. Understanding the warburg effect: The metabolic requirements of cell proliferation. Science. 2009; 324(5930):1029-33.

4. Newman DJ, Cragg GM. Natural products as sources of new drugs from 1981 to 2014. J Nat Prod. 2016;79:629-61.

5. Bean AR. A revision of Baeckea (Myrtaceae) in eastern Australia, Malesia and south-East Asia. Telopea. 1997;7:245-68.

6. Ahmad NS, Ghani MN, Manaf Ali A, Tajudin Tuan Johari SA, Harun MH. High Performance Liquid Chromatography (HPLC) Profiling Analysis and Bioactivity of Baeckea frutescens L. (Myrtaceae). J Plant Stud. 2012;1. https:// doi.org/10.5539/jps.v1n2p101.

7. Adib AM, Jamaludin F, Kiong LS, Hashim N, Abdullah Z. Two-dimensional correlation infrared spectroscopy applied to analyzing and identifying the extracts of Baeckea frutescens medicinal materials. J Pharm Biomed Anal. 2014;96:104-10.

8. Setzer WN, Vogler B, Schmidt JM, Leahy JG, Rives R. Antimicrobial activity of Artemisia douglasiana leaf essential oil. Fitoterapia; 2004.

9. Tsui WY, Brown GD. Sesquiterpenes from Baeckea frutescens. J Nat Prod. 1996;59:1084-6.

10. Fujimoto Y, Usui S, Making M, Sumatra M. Phloroglucinols from Baeckea frutescens. Phytochemistry. 1996;41:923-5.

11. Hou JQ, Guo C, Zhao JJ, He QW, Zhang BB, Wang H. Frutescone A-G, Tasmanone-based Meroterpenoids from the aerial parts of Baeckea frutescens. J Org Chem. 2017;82:1448-57.

12. Nisa K, Ito T, Kodama T, Tanaka M, Okamoto Y, Asakawa Y, et al. New cytotoxic phloroglucinols, baeckenones D-F, from the leaves of Indonesian Baeckea frutescens. Fitoterapia. 2016;109:236-40.

13. Nisa K, Ito T, Subehan MT, Kodama T, Morita H. New acylphloroglucinol derivatives from the leaves of Baeckea frutescens. Phytochem Lett. 2016;15:42-5.

14. Satake T, Kamiya K, Saiki Y, Hama T, Fujimoto Y, Endang H, et al. Chromone C-glycosides from Baeckea frutescens. Phytochemistry. 1999;50:303-6.

15. Tsui WY, Brown GD. Chromones and chromanones from Baeckea frutescens. Phytochemistry. 1996;43:871-6.

16. Tsui WY, Brown GD. Unusual metabolites of Baeckea frutescens. Tetrahedron. 1996:52:9735-42.

17. Quang TH, Cuong NX, Van Minh C, Van Kiem P. New Flavonoids from Baeckea Frutescens and their Antioxidant Activity. Nat Prod Commun. 2008; 3:1934578X0800300515.

18. Ito T, Nisa K, Kodama T, Tanaka M, Okamoto Y, Ismail, et al. Two new cyclopentenones and a new furanone from Baeckea frutescens and their cytotoxicities. Fitoterapia. 2016;112:132-5.

19. Jantan I, Ahmad AS, Bakar SAA, Ahmad AR, Trockenbrodt M, Chak CV. Constituents of the essential oil of Baeckea frutescens L. from Malaysia. Flavour Fragr J. 1998;13:245-7.

20. Jia BX, Jia A, Li CJ, Zhao HQ, Ren FX, Liu HM, et al. Baeckeins J and K, two novel $C$-methylated Biflavonoids from the roots of Baeckea frutescens and their Cytoprotective activities. Helv Chim Acta. 2016;99:499-505.

21. Jia B-X, Zeng X-L, Ren F-X, Jia L, Chen X-Q, Yang J, et al. Baeckeins F-I, four novel $\mathrm{C}$-methylated biflavonoids from the roots of Baeckea frutescens and their anti-inflammatory activities. Food Chem. 2014;155:31-7. https://doi. org/10.1016/j.foodchem.2014.01.022.

22. Jia BX, Yang J, Chen XQ, Cao Y, Lai MX, Wang Q. Baeckeins a and B, two novel 6-methylflavonoids from the roots of Baeckea frutescens. Helv Chim Acta. 2011;94:2283-8. 
23. Jia BX, Zhou YX, Chen XQ, Wang XB, Yang J, Lai MX, et al. Structure determination of baeckeins $C$ and $D$ from the roots of Baeckea frutescens. Magn Reson Chem. 2011;49:757-61.

24. Navanesan S, Wahab NA, Manickam S, Sim KS. Evaluation of selected biological capacities of Baeckea frutescens. BMC Complement Altern Med. 2015;15:186.

25. Mosmann T. Rapid colorimetric assay for cellular growth and survival: application to proliferation and cytotoxicity assays. J Immunol Methods. 1983:65:55-63.

26. Hassanein M, Weidow B, Koehler E, Bakane N, Garbett S, Shyr Y, et al. Development of high-throughput quantitative assays for glucose uptake in cancer cell lines. Mol Imaging Biol. 2011;13:840-52.

27. Shahruzaman SH, Mustafa MF, Ramli S, Maniam S, Fakurazi S, Maniam S. The cytotoxic properties of Baeckea frutescens branches extracts in eliminating breast Cancer cells. Evid Based Complement Alternat Med. 2019;2019:9607590.

28. Abdul Hisam EE, Rofiee MS, Khalid AM, Jalaluddin AF, Mohamad Yusof MI, Idris $\mathrm{MH}$, et al. Combined extract of moringa oleifera and Centella asiatica modulates oxidative stress and senescence in hydrogen peroxide-induced human dermal fibroblasts. Turkish J Biol. 2018;42(1):33-44

29. Dagogo-Jack I, Shaw AT. Tumour heterogeneity and resistance to cancer therapies. Nat Rev Clin Oncol. 2018;15(2):81-94.

30. Zardavas D, Irrthum A, Swanton C, Piccart M. Clinical management of breast cancer heterogeneity. Nat Rev Clin Oncol. 2015;12(7):381-94.

31. Cancer Chemotherapy National Service Center. Protocols for screening chemical agents and natural products against animal tumors and other biological systems. Cancer Chemother Rept. 1962;25:1-66.

32. Adekola K, Rosen ST, Shanmugam M. Glucose transporters in cancer metabolism. Curr Opin Oncol. 2012;24(6):650.

33. Medina RA, Owen Gl. Glucose transporters: expression, regulation and cancer. Biol Res. 2002;35(1):9-26.

34. Engelman JA, Chen L, Tan X, Crosby K, Guimaraes AR, Upadhyay R, et al. Effective use of PI3K and MEK inhibitors to treat mutant Kras G12D and PIK3CA H1047R murine lung cancers. Nat Med. 2008;14(12):1351-6.

35. Chan DA, Sutphin PD, Nguyen P, Turcotte S, Lai EW, Banh A, et al. Targeting GLUT1 and the Warburg effect in renal cell carcinoma by chemical synthetic lethality. Sci Transl Med. 2011;3(94):94ra70.

36. Kurniadewi F, Juliawaty LD, Syah YM, Achmad SA, Hakim EH, Koyama K, et al. Phenolic compounds from Cryptocarya konishii: their cytotoxic and tyrosine kinase inhibitory properties. J Nat Med. 2010;64(2):121-5.

37. Roos G, Röseler C, Büter KB, Simmen U. Classification and correlation of St. John's wort extracts by nuclear magnetic resonance spectroscopy, multivariate data analysis and pharmacological activity. Planta Med. 2004;70:771-7.

38. Ojeda P, Perez A, Ojeda L, Vargas-Uribe M, Rivas Cl, Salas M, et al. Noncompetitive blocking of human GLUT1 hexose transporter by methylxanthines reveals an exofacial regulatory binding site. AJP Cell Physiol. 2012;303(5):C530-9.

39. Vetterli L, Brun T, Giovannoni L, Bosco D, Maechler P. Resveratrol potentiates glucose-stimulated insulin secretion in INS-1E $\beta$-cells and human islets through a SIRT1-dependent mechanism. J Biol Chem. 2011;286(8):6049-60.

40. Hwang JK, Shim JS, Chung JY. Anticariogenic activity of some tropical medicinal plants against Streptococcus mutans. Fitoterapia. 2004;75:596-8.

41. Vu TT, Kim H, Tran VK, Le Dang Q, Nguyen HT, Kim H, et al. In vitro antibacterial activity of selected medicinal plants traditionally used in Vietnam against human pathogenic bacteria. BMC Complement Altern Med. 2016;16:32. https://doi.org/10.1186/s12906-016-1007-2.

42. Razmavar S, Abdulla MA, Ismail SB, Hassandarvish P. Antibacterial activity of leaf extracts of Baeckea frutescens against methicillin-resistant Staphylococcus aureus. Biomed Res Int. 2014;2014:521287.

43. Kamiya K, Satake T. Chemical constituents of Baeckea frutescens leaves inhibit copper-induced low-density lipoprotein oxidation. Fitoterapia. 2010;81:185-9.

44. Ito T, Nisa K, Rakainsa SK, Lallo S, Morita H. New phloroglucinol derivatives from Indonesian Baeckea frutescens. Tetrahedron. 2017;73:1177-81.

45. Jia BX, Ren FX, Jia L, Chen XQ, Yang J, Wang Q. Baeckein E, a new bioactive C-methylated biflavonoid from the roots of Baeckea frutescens. Nat Prod Res. 2013;27:2069-75.

46. Makino M, Fujimoto Y. Flavanones from Baeckea frutescens. Phytochemistry. 1999:50:273-7.

47. Tam NT, Thuam DT, Bighelli A, Castola V, Muselli A, Richomme P, et al. Baeckea frutescens leaf oil from Vietnam: composition and chemical variability. Flavour Fragr J. 2004;19:217-20.
48. Yu QW, Wang H, Huo JT, An XF, Gao P, Jiang ZZ, et al. Suppression of Baeckea frutescens $L$. and its components on MyD88-dependent NF-KB pathway in MALP-2-stimulated RAW264.7 cells. J Ethnopharmacol. 2017;207:92-9.

49. Lu WJ, Ya QK, Chen JY, Liu BM. A new flavonol glycoside from Baeckea Frutescens L. Yaoxue Xuebao. 2008:43:1032-5.

50. Raffa D, Maggio B, Raimondi MV, Plescia F, Daidone G. Recent discoveries of anticancer flavonoids. Eur J Med Chem. 2017;142:213-28.

51. Cai Y, Zhang J, Chen NG, Shi Z, Qiu J, He C, et al. Recent advances in anticancer activities and drug delivery systems of tannins. Med Res Rev. 2017;37(4):665-701.

52. Roleira FMF, Tavares-Da-Silva EJ, Varela CL, Costa SC, Silva T, Garrido J, et al. Plant derived and dietary phenolic antioxidants: anticancer properties. Food Chem. 2015;183:235-58

53. Yuan H, Ma Q, Cui H, Liu G, Zhao X, Li W, et al. How can synergism of traditional medicines benefit from network pharmacology? Molecules. 2017; 22(7):1135.

\section{Publisher's Note}

Springer Nature remains neutral with regard to jurisdictional claims in published maps and institutional affiliations.
Ready to submit your research? Choose BMC and benefit from:

- fast, convenient online submission

- thorough peer review by experienced researchers in your field

- rapid publication on acceptance

- support for research data, including large and complex data types

- gold Open Access which fosters wider collaboration and increased citations

- maximum visibility for your research: over $100 \mathrm{M}$ website views per year

At BMC, research is always in progress.

Learn more biomedcentral.com/submissions 